Article

\title{
Potential of Ceria-Zirconia-Based Materials in Carbon Soot Oxidation for Gasoline Particulate Filters
}

\author{
Eleonora Aneggi *(D) and Alessandro Trovarelli ${ }^{(D)}$ \\ Dipartimento Politecnico di Ingegneria e Architettura, Università di Udine, Unità di Ricerca INSTM Udine, \\ 33100 Udine, Italy; alessandro.trovarelli@uniud.it \\ * Correspondence: eleonora.aneggi@uniud.it; Tel.: +39-0432-558830
}

Received: 22 June 2020; Accepted: 7 July 2020; Published: 9 July 2020

\begin{abstract}
ZrO}_{2}$ and $\mathrm{Ce}_{0.8} \mathrm{Zr}_{0.2} \mathrm{O}_{2}$ mixed oxides were prepared and tested in the oxidation of carbon soot at different oxygen partial pressures and degrees of catalyst/soot contact to investigate their activity under typical gasoline direct injection (GDI) operating conditions. Under reductive atmospheres, generation of oxygen vacancies occurs in $\mathrm{Ce}_{0.8} \mathrm{Zr}_{0.2} \mathrm{O}_{2}$, while no reduction is observed on $\mathrm{ZrO}_{2}$. Both materials can oxidize carbon under high oxygen partial pressures; however, at low oxygen partial pressures, the presence of carbon can contribute to the reduction of the catalyst and formation of oxygen vacancies, which can then be used for soot oxidation, increasing the overall performance. This mechanism is more efficient in $\mathrm{Ce}_{0.8} \mathrm{Zr}_{0.2} \mathrm{O}_{2}$ than $\mathrm{ZrO}_{2}$, and depends heavily on the interaction and the degree of contact between soot and catalyst. Thus, the ability to form oxygen vacancies at lower temperatures is particularly helpful to oxidize soot at low oxygen partial pressures, and with higher $\mathrm{CO}_{2}$ selectivity under conditions typically found in GDI engine exhaust gases.
\end{abstract}

Keywords: ceria-zirconia; zirconia $\mathrm{ZrO}_{2}$; oxygen storage capacity; particulate; oxidation; gasoline particulate filters

\section{Introduction}

The gasoline engine market, based on direct injection (DI) technology is growing rapidly, especially in relation to their better efficiency and lower $\mathrm{CO}_{2}$ emissions [1]. In addition, for 2020 the European Union has imposed a limit on $\mathrm{CO}_{2}$ emissions for cars of $95 \mathrm{~g} / \mathrm{km}$; the GDI engines are able to increase fuel economy, and consequently reduce these emissions [2]. On the other hand, however, these engines produce a higher amount of soot than conventional gasoline engines. In particular, attention is focused not only on particulate emissions (PM), but also on the particulate number (PN), and consequently it is necessary to implement new emission control strategies [3]. As required for diesel engines, it is possible to introduce a particulate filter to reduce emissions of soot: the so-called gasoline particulate filter (GPF) [4-6]. However, due to the different operating conditions of a diesel engine and a GDI engine [3], it is not possible to simply transfer the technologies optimized and developed in the last twenty years for diesel particulate filters (DPF), but it is necessary to investigate in detail the mechanisms of soot accumulation and oxidation under typical GDI operating conditions [7]. Exactly as it happens for DPFs, the accumulation phase must necessarily be followed by a regeneration phase, in order to oxidize the accumulated soot and prevent an increased pressure drop [8]. Since particulate oxidizes at around $600{ }^{\circ} \mathrm{C}$, in order to save fuel and to avoid filter damage, a catalyst impregnated on the filter, which lowers the combustion temperature, can be used. To ensure regeneration, however, issues arising from the different atmosphere of the exhaust gas of a GDI and a diesel engine must be taken into consideration [3]. In the diesel engine, in fact, regeneration is favored by the high oxygen content and by the presence of nitrogen oxides, $\mathrm{NO}_{x}$, which participate in the oxidation reaction. Consequently, the catalyst formulations developed for the DPFs cannot be directly transferred to the GDI engines, 
in which the oxygen content is low with a lower $\mathrm{NO}_{x}$ content [9]. In addition, due to the low oxygen concentration, special attention should be paid to $\mathrm{CO} / \mathrm{CO}_{2}$ selectivity in order to limit the formation of CO. Studies on catalytic GPF systems are still in the initial stages. If a search is made on WoS using "gasoline particulate filter" and "catalyst" as keywords, there are ca. 50 articles in the last five years, while in the same timeframe the keywords "diesel particulate filter" and "catalyst" returns almost 260 items.

Since 2015, only few studies were focused on catalytic materials for GDI, and specifically the family of perovskites and ceria-based oxide formulations have been primarily investigated. La/Sr-based $[10,11]$ and $\mathrm{Cu}$-doped $\mathrm{BaFeO}_{3}$ perovskites [12] are suitable to oxidize soot at low oxygen partial pressures, thanks to their redox properties and oxygen surface vacancies, by transporting bulk oxygen to the catalyst-soot contact points. Surface lattice oxygen and oxygen adsorbed on vacancies are key factors in soot oxidation under GPF conditions over $\alpha-\mathrm{Mn}_{2} \mathrm{O}_{3}$, with more than $99 \% \mathrm{CO}_{2}$ selectivity [13]. Ceria-based catalysts have been extensively studied in DPF systems [14-20], and could also be promising for GPF thanks to their oxygen storage capacity (OSC) properties. Cerium oxide has the ability to rapidly modify its oxidation state from $\mathrm{Ce}^{4+}$ to $\mathrm{Ce}^{3+}$, releasing oxygen and maintaining structural integrity under a reducing atmosphere, while when the atmosphere is lean, oxygen uptake and the reoxidation of $\mathrm{Ce}^{3+}$ to $\mathrm{Ce}^{4+}$ is observed [21-23]. The unique redox behavior of ceria is the key of the success of ceria-based materials in catalysis, and more specifically it contributes to the mechanism of soot oxidation by promoting the formation of oxygen vacancies at the interface between ceria and carbon, which is the key point to obtain active surface oxygen species [24-26]. Silver on ceria has been extensively investigated as a catalyst for diesel soot oxidation [27-30], and recently, several studies have been related to its application under conditions typical of gasoline engines. Weng et al. [9,31-33] found that $\mathrm{Ag} / \mathrm{Ce}$ is a promising material for soot oxidation, due to the bulk-to-surface oxygen migration. They also developed core-shell $\mathrm{Ag} / \mathrm{M}_{\mathrm{x}} \mathrm{O}_{\mathrm{y}} @ \mathrm{CeO}_{2}$ materials (with $\mathrm{M}=\mathrm{Fe}$ or $\mathrm{Co}$ ) with a tandem oxygen delivery route $\left(\mathrm{M}_{x} \mathrm{O}_{y} \rightarrow \mathrm{CeO}_{2} \rightarrow \mathrm{Ag}\right)$, resulting in an efficient transfer of bulk oxygen to soot [33,34]. Ceria has also been found to deliver active oxygen to the surface and to silver nanoparticles in $\mathrm{Ag}-\mathrm{CeO}_{2}$ materials, and also act as an oxygen collector, improving soot oxidation under low oxygen concentration [35]. A few studies on unsupported Ce-based oxides for soot oxidation in GPF conditions are also reported, and are mainly focused on the relations between activity and OSC and redox behavior [36-39]. Overall, it seems that OSC properties of ceria and its high oxygen mobility could help in promoting the release of oxygen, and provide an additional mechanism route to oxidize carbon particles when oxygen content is low. However, direct comparison of results in the literature is quite difficult, due to the many parameters that are taken into consideration, and which influence activity, such as the effect of type of soot and kind of soot/catalyst contact, the soot/catalyst ratio and the oxygen concentration. Here we have investigated the soot combustion reaction over $\mathrm{Ce}_{0.8} \mathrm{Zr}_{0.2} \mathrm{O}_{2}$ and $\mathrm{ZrO}_{2}$ (as an example of reducible and non-reducible materials, respectively), with a specific focus on the influence of the atmosphere of reaction (from inert gas to air) and of the type of carbon/catalyst interaction by varying the way soot and catalyst were put into contact. For this reason, three different contact conditions were employed with varying degrees of carbon/catalyst interactions, which were previously characterized at a nanoscale level $[40,41]$. This allowed us to monitor the oxidation ability of modified ceria at low oxygen pressure, as a function of the degree of interaction between carbon soot and surface ceria oxygens, and verify that this formulation could represent a good starting point for the development of catalysts for GPF systems.

\section{Results and Discussion}

\subsection{Textural, Structural and Redox Characterization of Soot/Catalyst Mixtures}

Two types of mixing conditions have been employed to put into contact carbon soot and catalysts to simulate different degrees of interactions. For loose contact, soot and catalyst have been mixed in a vial for two minutes, which is representative of the weak degree of interaction that is found in 
real systems. Tight contact has been obtained by grinding the mixture in an agate mortar for ten minutes. This is less representative of real conditions, but results are generally more reproducible, and a much stronger interaction is observed [42]. A third type of mixing has only been employed in the case of ceria-zirconia, and it is realized by milling powders for $8 \mathrm{~h}$ in a high-energy mill to obtained a supertight contact [40]. This is not representative of the real application, but it is a good reference for a high degree of redox interaction that can be obtained between carbon and catalyst, and is useful in the understanding of the mechanism of reaction and on the intrinsic activity of reducible materials. This contact is characterized by a different morphology, where a layer of soot forms a thin shell covering ceria-zirconia crystallite cores promoting interactions at a nanoscale at the ceria-zirconia/carbon interface $[40,41]$. The different contact modes are represented in Scheme 1.

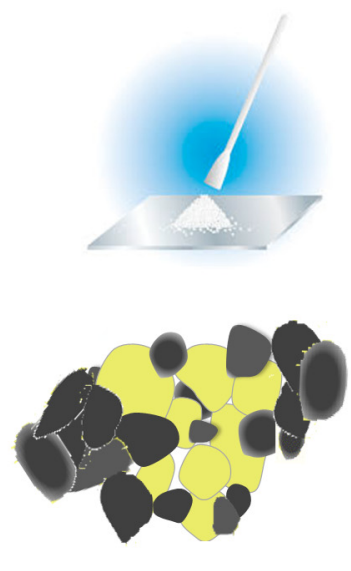

Loose contact
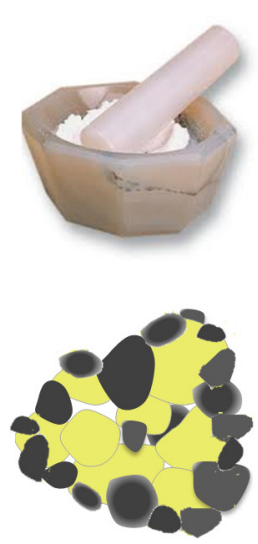

Tight contact
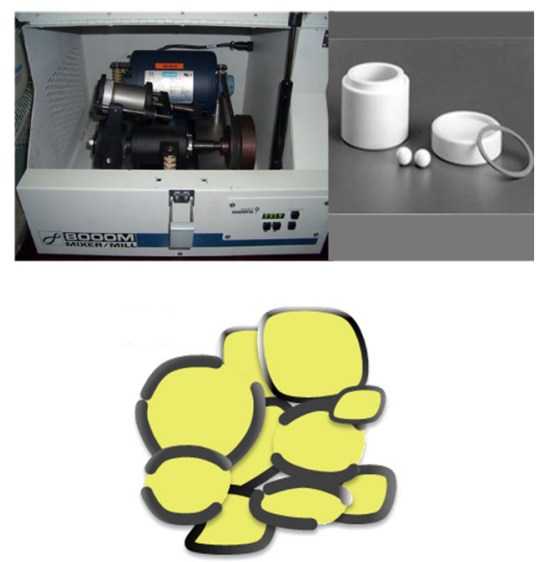

Supertight contact

Scheme 1. Different kinds of contact obtained by mixing soot (black) and catalyst (yellow) using a spatula, an agate mortar and a high-energy mill.

The composition and BET surface area of investigated materials are reported in Table 1. Ceria-zirconia and zirconia show a surface area in the range of $60-80 \mathrm{~m}^{2} / \mathrm{g}$. When soot is mixed with the catalyst in a loose and tight contact mode, the surface area is not affected, while the surface area of ceria-zirconia decreases by effect of milling from 79 to $29 \mathrm{~m}^{2} / \mathrm{g}$. This is typically observed upon the milling of high surface area powders, and is probably due to the adhesion of fine crystallites on the surface of larger particles $[40,43]$.

Table 1. Composition and textural characterization of investigated samples.

\begin{tabular}{|c|c|c|}
\hline Sample & Name & Surface Area $\left(\mathrm{m}^{2} / \mathrm{g}\right)$ \\
\hline $\mathrm{Ce}_{0.8} \mathrm{Zr}_{0.2} \mathrm{O}_{2}$ & $\mathrm{CZ}$ & 79 \\
\hline $\mathrm{Ce}_{0.8} \mathrm{Zr}_{0.2} \mathrm{O}_{2}+5$ wt. \% soot (loose contact) & CZL & 79 \\
\hline $\mathrm{Ce}_{0.8} \mathrm{Zr}_{0.2} \mathrm{O}_{2}+5$ wt. \% soot (tight contact) & CZT & 78 \\
\hline $\mathrm{Ce}_{0.8} \mathrm{Zr}_{0.2} \mathrm{O}_{2}+5$ wt. \% soot (supertight contact) & CZST & 29 \\
\hline $\mathrm{ZrO}_{2}$ & $\mathrm{Zr}$ & 64 \\
\hline $\mathrm{ZrO}_{2}+5$ wt. $\%$ soot (loose contact) & $\mathrm{ZrL}$ & 64 \\
\hline $\mathrm{ZrO}_{2}+5$ wt. $\%$ soot (tight contact) & $\mathrm{ZrT}$ & 62 \\
\hline $\operatorname{Soot}^{a}$ & $S$ & 6 \\
\hline
\end{tabular}

a: soot mixed with powder quartz in 1:20 proportions.

X-ray diffraction (XRD) profiles are shown in Figure $1 \mathrm{~A}, \mathrm{~B} . \mathrm{ZrO}_{2}$ shows the simultaneous presence of tetragonal (space group P42/nmc; main reflection at $30.2^{\circ}$ ) and monoclinic $\mathrm{ZrO}_{2}$ (space group P121/c1; main reflection at $28.2^{\circ}$ ) and milling with soot does not modify the XRD profile. Ceria-zirconia (CZ) catalysts (Figure 1B) exhibit reflections characteristic of a pure fluorite phase. The soot/CZ mixture in loose and tight contact do not evidence any difference with parent $\mathrm{CZ}$. The XRD profiles do not 
show significant modification of the ceria-zirconia structure, and all samples are indexed in a fluorite cubic cell. The CZST sample shows a sharpening of XRD signals due to an increase of the particle size. In addition, a small signal appears at ca. 30.5 degrees, due to the main reflection of the (011) plane of $\mathrm{ZrO}_{2}$, originating from abrasion during milling. Rietveld analysis also reveals a small decrease of the lattice cell parameter due to insertion of $\mathrm{ZrO}_{2}$ into $\mathrm{CZ}$, with a slight change in stoichiometry of solid solution that goes from $\mathrm{Ce}_{0.8} \mathrm{Zr}_{0.2} \mathrm{O}_{2}$ to $\mathrm{Ce}_{0.78} \mathrm{Zr}_{0.22} \mathrm{O}_{2}$ in agreement with previous observations [40]. No signals of reaction between the oxide and carbon are revealed by XRD.
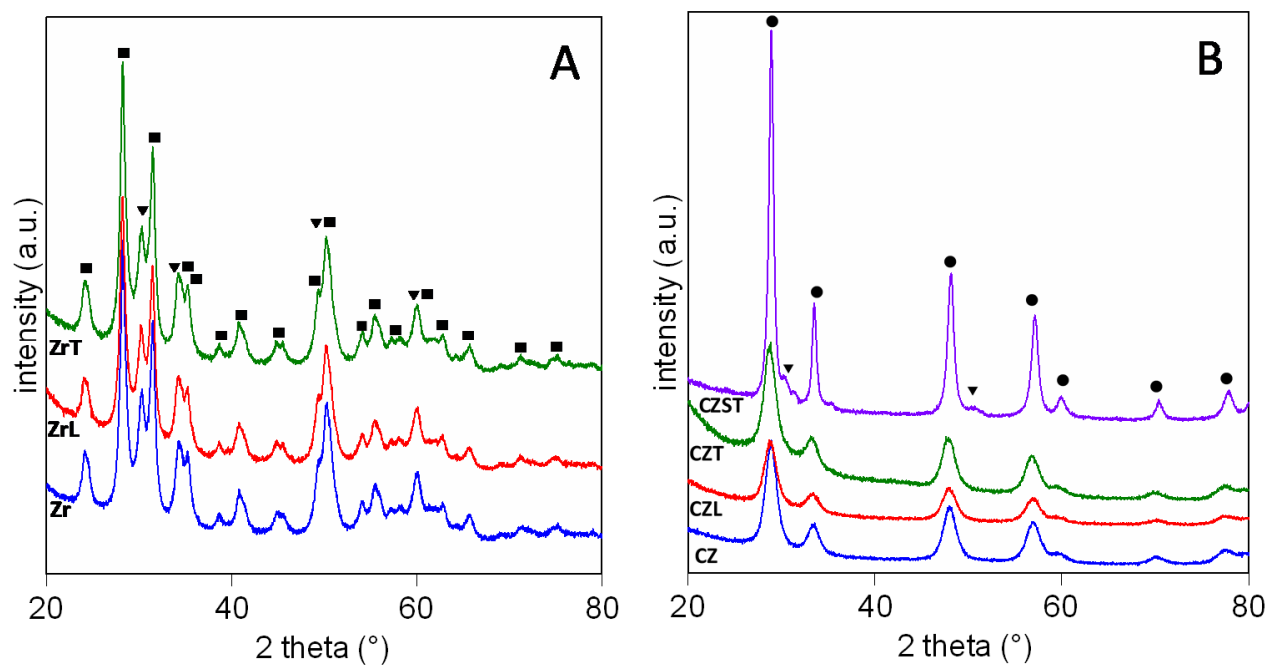

Figure 1. X-ray diffraction (XRD) profile of (A) zirconia-based materials $\left(\mathrm{ZrO}_{2}\right.$ monoclinic, $\mathbf{\mathbf { a }} ; \mathrm{ZrO}_{2}$ tetragonal, $\mathbf{v})$; and (B) ceria-zirconia-based materials $\left(\mathrm{Ce}_{0.8} \mathrm{Zr}_{0.2} \mathrm{O}_{2}, \bullet ; \mathrm{ZrO}_{2}\right.$ tetragonal, $\left.\mathbf{v}\right)$.

In order to characterize the reduction behavior of the materials and understand the role of carbon in the removal of lattice oxygen, we have further investigated the redox and oxygen storage properties of pure catalyst and catalyst soot mixtures under different contact conditions by $\mathrm{H}_{2}$-TPR and OSC measurements; the results are summarized in Figures 2 and 3, respectively. For zirconia, a temperature-programmed reduction (TPR) feature of a typical non-reducible support was found, while $\mathrm{CZ}$ shows one broad hydrogen uptake peak centered at around $558^{\circ} \mathrm{C}$, due to the reduction of surface and bulk $\mathrm{Ce}^{4+}$ cations [44]. In carbon-containing samples, the $\mathrm{H}_{2}$ consumption peak shifts to progressively lower temperatures as the contact become more intimate. The reduction peak for bare $\mathrm{CZ}$ centered at $558{ }^{\circ} \mathrm{C}$ progressively shifts to 530,506 and $420{ }^{\circ} \mathrm{C}$, respectively for loose, tight and supertight contact, with an overall reduction degree, similar for all the investigated samples, of $45 \%$. No evidence for reduction is found in $\mathrm{Zr}$ samples. In bare $\mathrm{CZ}$, the reduction peak is correlated to consumption of $\mathrm{H}_{2}$ with the formation of $\mathrm{H}_{2} \mathrm{O}$. With $\mathrm{CZ} /$ soot mixtures, the outlet gas composition has been followed by MS/FTIR, indicating the production of $\mathrm{H}_{2} \mathrm{O}$ (see inset of Figure 2A), with no formation of $\mathrm{CH}_{4}$, thus excluding the reduction of carbon by hydrogen. Figure $2 \mathrm{C}, \mathrm{D}$ show $\mathrm{CO}$ formation profiles in TPR, as followed by Fourier-transform infrared spectroscopy (FTIR). Pure CZ shows the development of a very low amount of $\mathrm{CO}$ at around $600{ }^{\circ} \mathrm{C}$, likely related to the desorption of residual carbonate species adsorbed on the surface. When soot/catalyst mixtures are investigated, the amount of $\mathrm{CO}$ formed during the reaction increases by increasing the contact with soot. No evidence for $\mathrm{CO}$ formation is observed in $\mathrm{Zr}$ samples, regardless of the contact conditions. Overall, these results indicate that deposited carbon promotes the reduction of ceria-zirconia as a function of the degree of interaction with the surface; the more robust the carbon/ceria contact, the lower the reduction temperature. This is particularly evident in CZST, where the morphology of carbon distributed as a thin envelope on the surface of the catalyst acts as a booster for the reduction reaction, with a reduction profile centered $140{ }^{\circ} \mathrm{C}$ lower than bare $\mathrm{CZ}$. One possible mechanism is that carbon at the interface forms $\mathrm{C}-\mathrm{O}^{*}$ adsorbed species that act as a driving force for the reduction of the material. This adsorbed 
oxygen then reacts more easily with hydrogen, forming $\mathrm{H}_{2} \mathrm{O}$. In other words, carbon, when finely dispersed over ceria-zirconia, can act as a catalyst for ceria-zirconia reduction reaction. Traces of CO are also formed by direct oxidation of carbon with lattice oxygen; again, these are more evident in CZST, where the carbon is finely dispersed over ceria-zirconia.
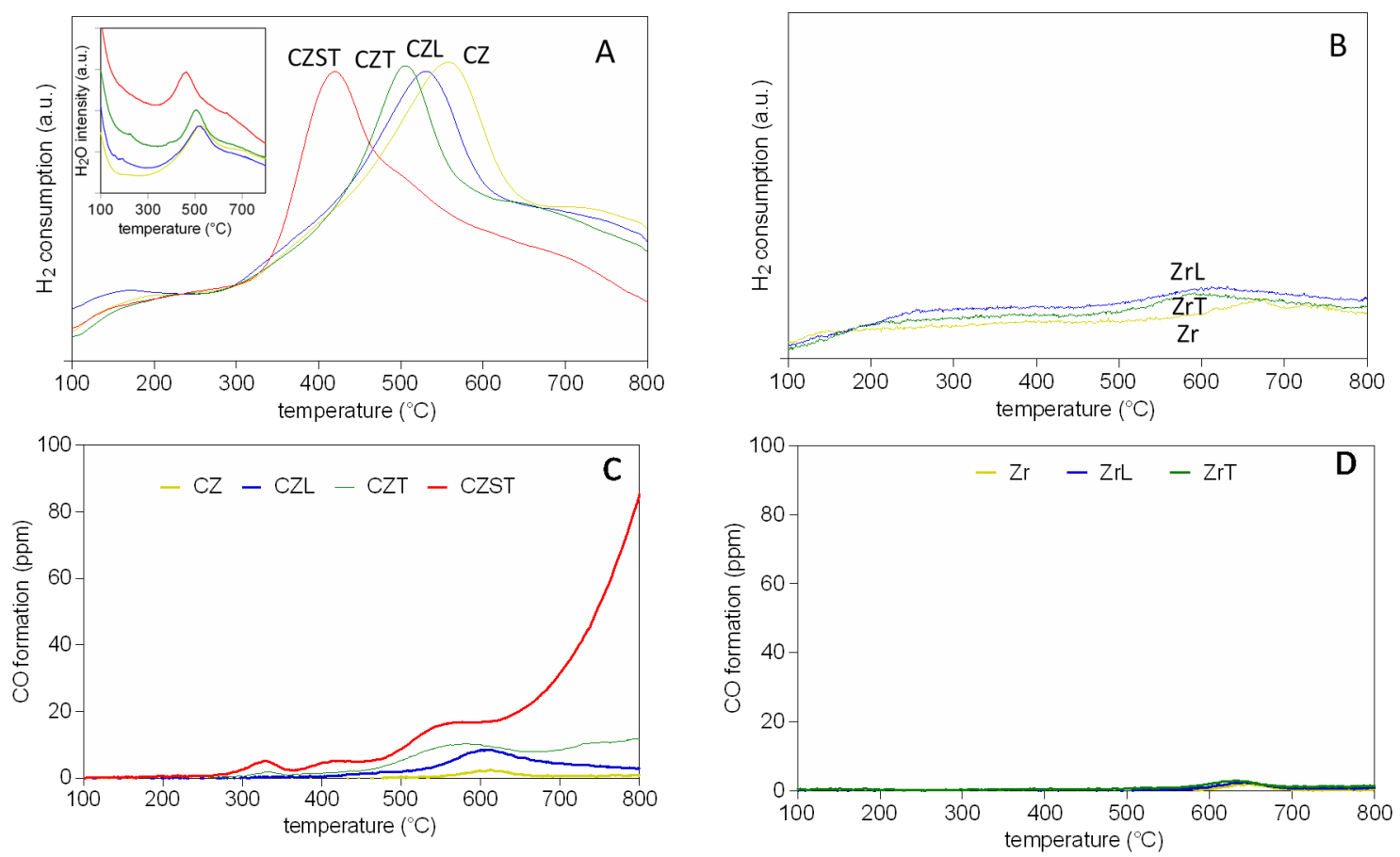

Figure 2. (A) $\mathrm{H}_{2}$-TPR profile of pure ceria-zirconia $(\mathrm{CZ})$ and $\mathrm{CZ} /$ soot mixtures under different contact conditions, (B) $\mathrm{H}_{2}$-TPR profile of pure zirconia $(\mathrm{Zr})$ and $\mathrm{Zr}$ /soot mixtures under different contact conditions; (C,D) $\mathrm{CO}$ formation from $\mathrm{H}_{2}$-TPR followed by FTIR gas analysis. The inset in (A) shows $\mathrm{H}_{2} \mathrm{O}$ profiles in temperature-programmed reduction (TPR), followed by mass spectrometry (MS) analysis.

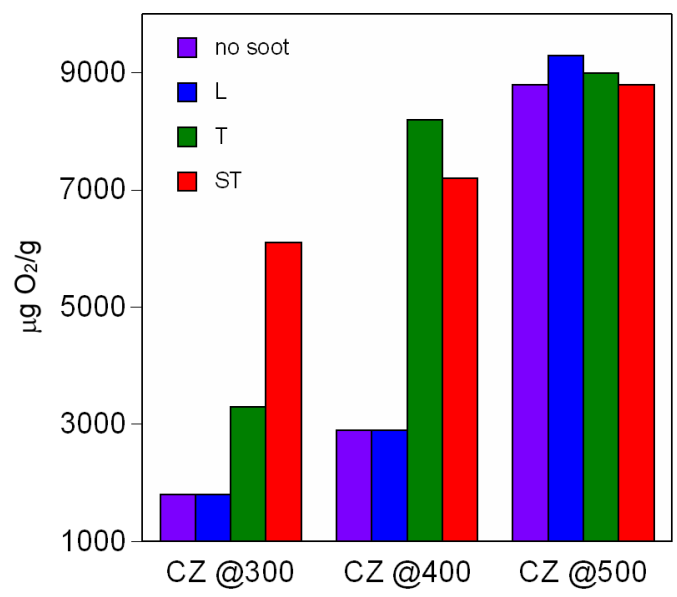

Figure 3. Oxygen storage capacity (OSC) results from thermal gravimetric analysis (TGA) analysis for different contact conditions.

Similar results are confirmed by oxygen storage capacity analysis carried out on pure zirconia and ceria-zirconia, and on soot-catalyst mixtures at different temperatures, as seen in Figure 3. The data were collected according to the method described in the experimental part; zirconia, as expected, 
does not show any measurable oxygen storage capacity, while OSC of ceria-zirconia increases from $1796 \mu \mathrm{g} \mathrm{O} / 2 / \mathrm{g}$ at $300{ }^{\circ} \mathrm{C}$, to 2922 and $8762 \mu \mathrm{g} \mathrm{O} / \mathrm{g}$, respectively, at $400{ }^{\circ} \mathrm{C}$ and $500{ }^{\circ} \mathrm{C}$. For bare $\mathrm{CZ}$ and $\mathrm{CZL}$, removal of oxygen is similar in the temperature range investigated, while for tight and supertight contact, a higher OSC has been found, confirming the enhanced "reducibility" of the material in the presence of soot.

Carbon particles can act as an "activator" of the oxygen, moving it towards the surface and making it more available for the hydrogen present in the gas phase, as depicted in Scheme 2. The higher the contact between carbon and the catalyst, the higher the amount of oxygen that can be transferred at a lower temperature.

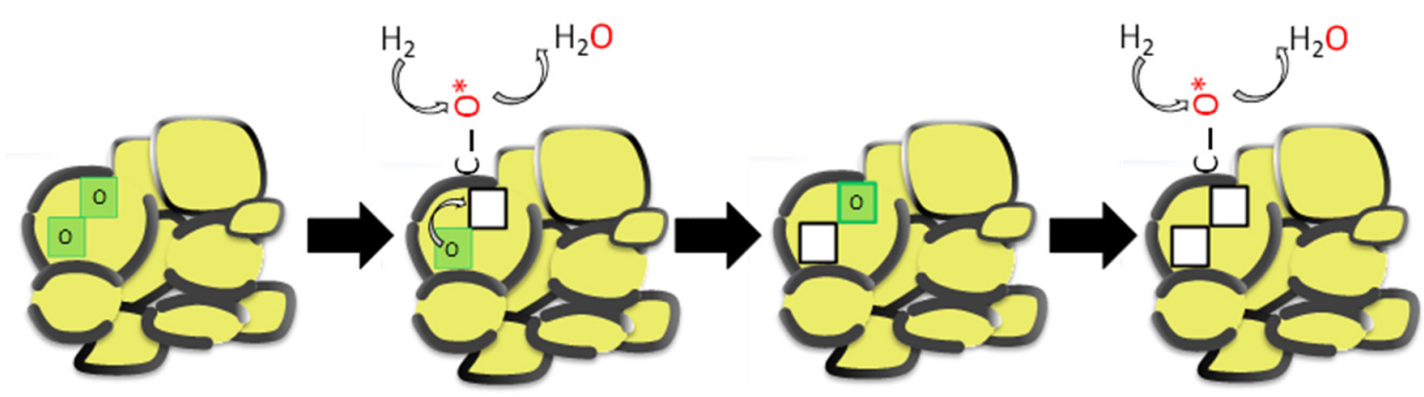

Scheme 2. Mechanism of reaction for oxygen transfer over soot/CZ mixtures.

\subsection{Catalytic Activity}

The catalytic activity has been investigated by means of thermogravimetric experiments and temperature programmed oxidation under different oxygen concentration, with the objective to understand whether a reducible $\mathrm{CZ}$ and a non-reducible $\mathrm{Zr}$ material can be used under oxygen conditions, simulating those of gasoline exhaust gases, in which the amount of oxygen is typically low. Representative weight loss profiles obtained for bare soot and $\mathrm{CZ}$ in loose contact under different atmospheres (air, $1 \% \mathrm{O}_{2} / \mathrm{N}_{2}$ and $\mathrm{N}_{2}$ ) are shown in Figure 4 .
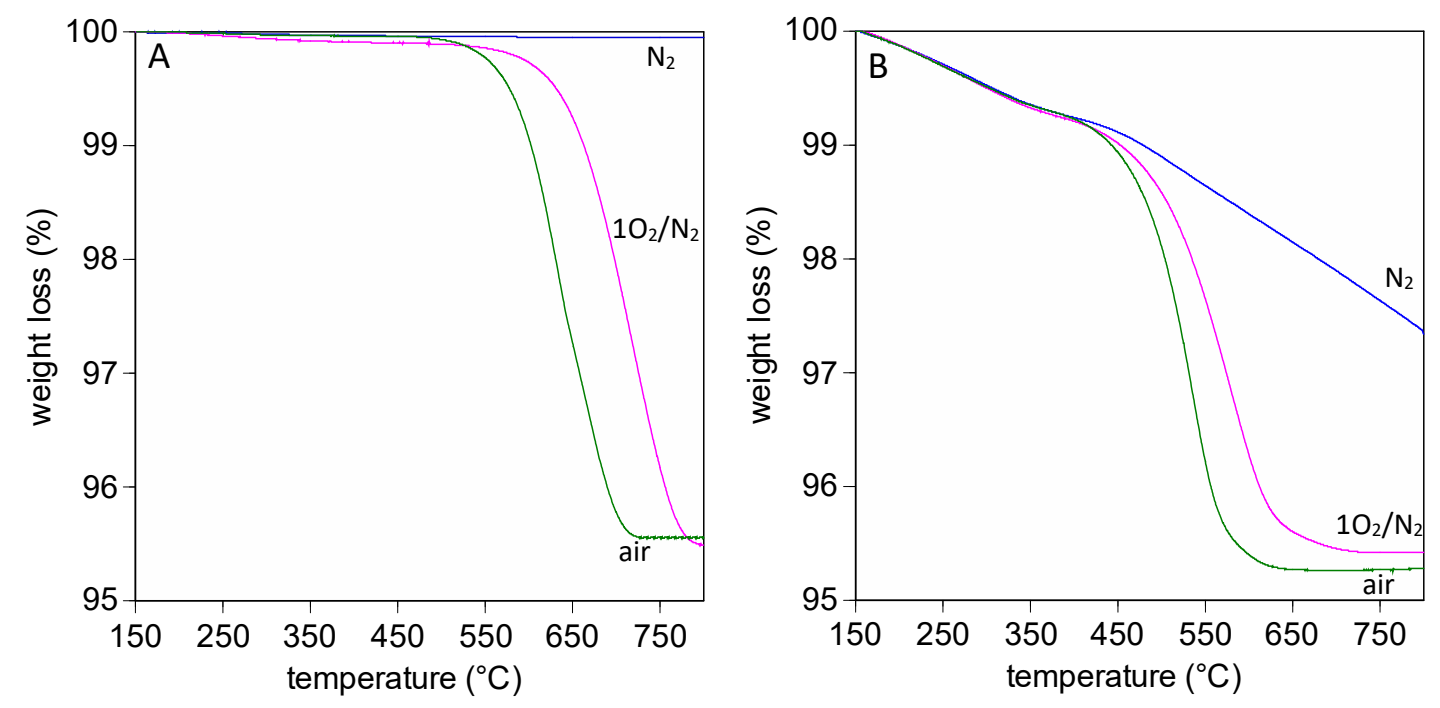

Figure 4. Weight loss profiles obtained from TGA analysis of bare soot (A) and CZL (B) under different atmospheres (air, $1 \% \mathrm{O}_{2}$ in $\mathrm{N}_{2}$ and $\mathrm{N}_{2}$ ).

The non-catalytic reaction (Figure $4 \mathrm{~A}$ ) is strongly dependent on the amount of oxygen in the gas phase. Under inert atmosphere a negligible weight loss is observed, while in the presence of $\mathrm{O}_{2}$ a complete oxidation is reached with a $\mathrm{T} 50$ of $705{ }^{\circ} \mathrm{C}\left(1 \mathrm{O}_{2} / \mathrm{N}_{2}\right)$ and $630{ }^{\circ} \mathrm{C}$ (air). When soot is 
mixed with CZ in loose contact mode (Figure 4B), a remarkable increase in the activity is achieved independently of the $\mathrm{O}_{2}$ concentration. The oxidation of carbon in CZL in the absence of oxygen is not quantitative, and is associated with the oxidation of the soot by the surface/bulk oxygens of ceria-zirconia. The weight loss $(2.7 \%)$ is due to the formation of $\mathrm{CO} / \mathrm{CO}_{2}$ evolving from the system, and it also accounts for the lattice oxygen of $\mathrm{CZ}$ used for oxidation during the reaction. Weight loss in $1 \% \mathrm{O}_{2} / \mathrm{N}_{2}$ and in air shows very similar profiles, but when a lower amount of oxygen is used, a shift of the oxidation curve profile to higher temperature is observed; in particular, T50 shifts from $515^{\circ} \mathrm{C}$ for reaction under air to $545{ }^{\circ} \mathrm{C}$ for reaction in $1 \% \mathrm{O}_{2} / \mathrm{N}_{2}$.

Figure 5 shows the T50 for all the investigated catalysts as a function of the reaction atmosphere. Under an inert atmosphere, weight loss is negligible in bare soot and in zirconia/soot mixtures regardless of the contact type; this is consistent with the lack of lattice oxygen available for promotion of redox reaction in zirconia and the lack of volatile matter in soot composition, which can be released during thermal treatment. No oxidation is therefore observed in these samples under an inert atmosphere. With the introduction of ceria in $\mathrm{CZ}$, a higher activity can be observed already under inert atmosphere, with a T50 for the loose contact of $775{ }^{\circ} \mathrm{C}$, which progressively decreases to 546 and $420^{\circ} \mathrm{C}$ for tight and supertight contact, respectively. This is consistent with the fact that ceria-zirconia-based systems can use the surface/bulk oxygen to oxidize soot even in the absence of oxygen in the gas phase, through the oxidation of carbon at the carbon/CZ interface with the formation of an oxygen vacancy [24,45]. The oxidation reaction proceeds to consume available oxygen, and the activity is closely related to the amount of reducible oxygen/OSC, and is progressively inhibited due to the lack of reoxidation of the material when the inert gas phase is used [46,47]. The introduction of oxygen facilitates oxidation in all formulations. If we focus on $\mathrm{CZ}$, we can observe that the catalytic activity in $1 \% \mathrm{O}_{2} / \mathrm{N}_{2}$ slightly differs from that in air $\left(\Delta \mathrm{T} 50\right.$ close to $\left.25 / 35^{\circ} \mathrm{C}\right)$, while for $\mathrm{Zr}$ materials the $\mathrm{T} 50$ in $1 \% \mathrm{O}_{2} / \mathrm{N}_{2}$ is $70 / 80{ }^{\circ} \mathrm{C}$, which is higher compared to oxidation in air. In the case of zirconia, the change of oxygen concentration heavily affects T50, as carbon reacts directly with $\mathrm{O}$ from the gas phase, while in CZ materials the dependence on the amount of oxygen in the gas phase is less significant, and mediated by the available oxygen from the $\mathrm{CZ}$ surface. Therefore, even when the oxygen concentration is very low, ceria-based materials are able to release their surface/bulk oxygen to oxidize the soot with formation of vacancies that are refilled through oxygen of the gas phase, promoting oxidation. It is therefore the oxygen from ceria that sustains the catalytic activity through a mechanism that exploits both the available surface oxygen and the bulk oxygen [47].

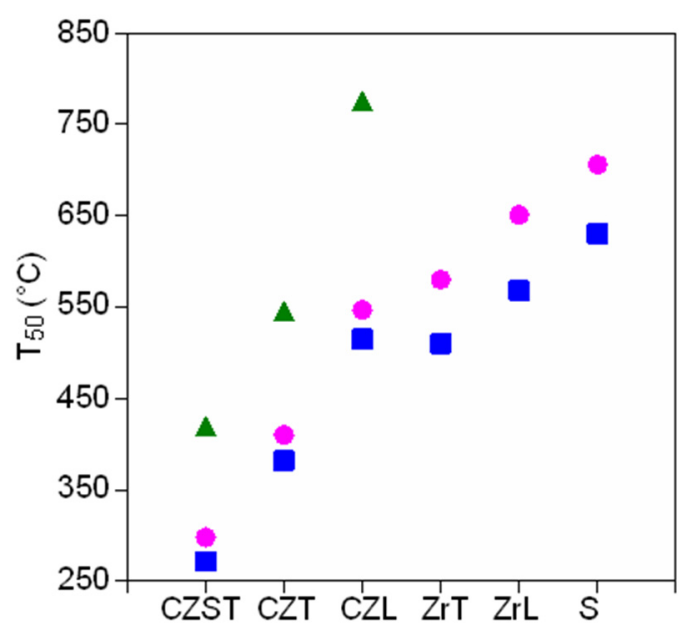

Figure 5. TGA results as $T_{50}$ for different contact and different atmosphere $\left(\mathbf{\square}\right.$, air; $\left.\bullet, 1 \% \mathrm{O}_{2} / \mathrm{N}_{2} ; \Delta, \mathrm{N}_{2}\right)$.

The catalytic activity for the combustion of soot was also determined from peak-top temperature (Tm) during temperature programmed oxidation (TPO) of catalyst/soot mixtures under 
$10 \% \mathrm{O}_{2} / \mathrm{N}_{2}$ or $1 \% \mathrm{O}_{2} / \mathrm{N}_{2}$, mainly to verify gas composition after combustion and evaluate the selectivity to $\mathrm{CO}_{2}$. Figure 6 compares $\mathrm{CO}$ and $\mathrm{CO}_{2}$ profiles of all samples.
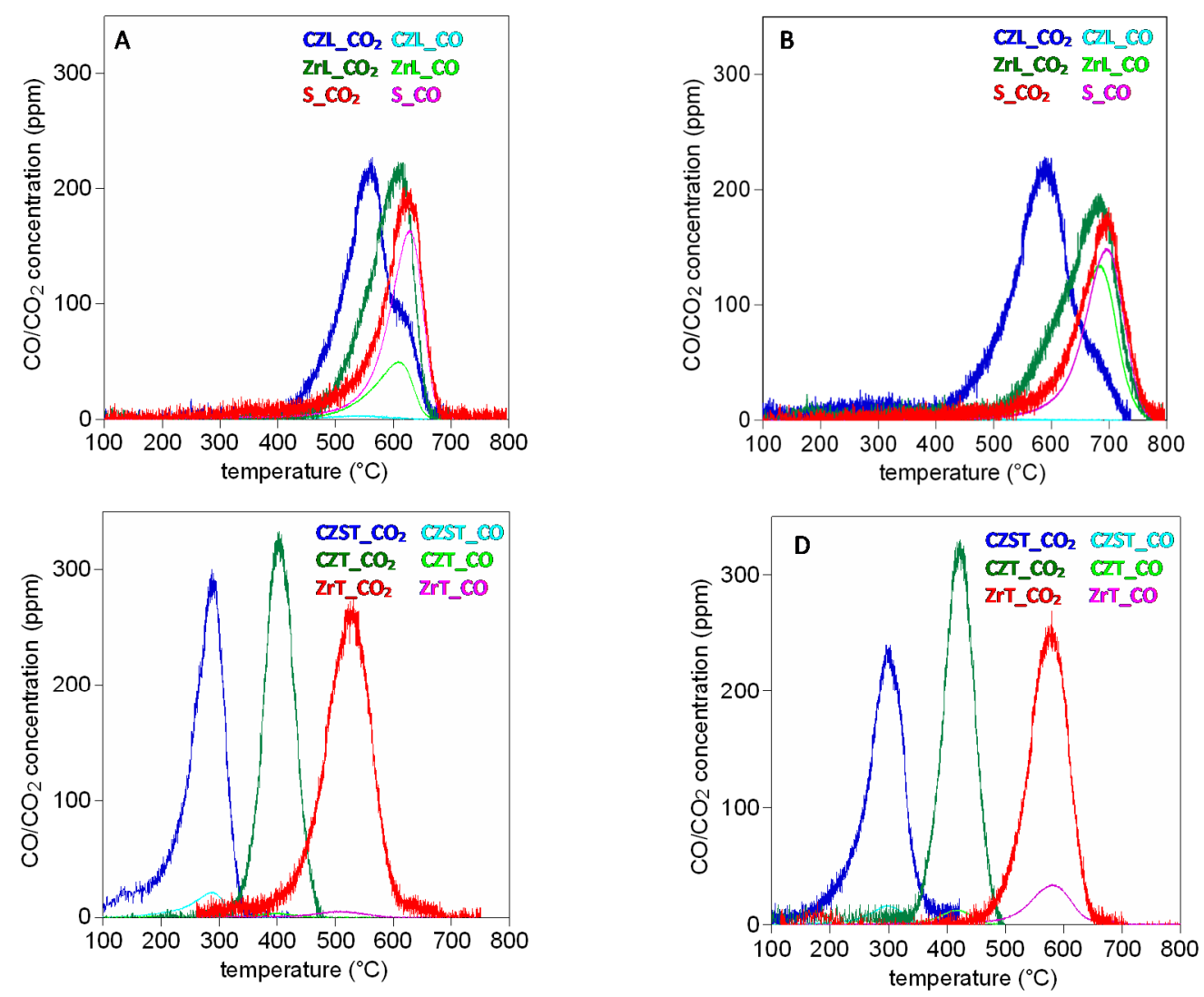

Figure 6. $\mathrm{CO} / \mathrm{CO}_{2}$ profiles from temperature programmed oxidation (TPO) in $10 \% \mathrm{O}_{2} / \mathrm{N}_{2}(\mathrm{~A}, \mathrm{C})$ and $1 \%$ $\mathrm{O}_{2} / \mathrm{N}_{2}(\mathbf{B}, \mathbf{D})$.

The results are in agreement with those obtained from TGA, with ceria-zirconia displaying a lower oxidation temperature than zirconia for any contact conditions, and regardless of oxygen content. Selectivity to $\mathrm{CO}_{2}$ is always higher than $97 \% @ 1 \% \mathrm{O}_{2}$, compared to a value of $60-80 \%$ obtained with $\mathrm{Zr}$. The data are summarized in Table 2; it can be observed that selectivity to $\mathrm{CO}_{2}$ in $\mathrm{ZrL}$ at $1 \%$ oxygen is comparable to selectivity in bare soot. Selectivity in ceria-zirconia systems is only negligibly affected by the different oxygen concentration and contact conditions, while in bare soot and Zr-based samples, the $\mathrm{CO} / \mathrm{CO}_{2}$ ratio is strongly influenced by atmosphere and carbon catalyst contact. In particular, zirconia at low oxygen concentration in loose conditions has negligible catalytic activity and selectivity $\left(\mathrm{Tm}=680^{\circ} \mathrm{C}\right.$, Sel $=63 \%$ ), which is increased under tight conditions, as well as $10 \%$ oxygen, to reach $97 \%$ with a $\mathrm{Tm}$ of $535^{\circ} \mathrm{C}$.

Table 2. $\mathrm{CO}_{2}$ selectivity from TPO experiments.

\begin{tabular}{ccc}
\hline Sample & $\mathbf{1 \%} \mathbf{O}_{\mathbf{2}} / \mathbf{N}_{\mathbf{2}}$ & $\mathbf{1 0} \% \mathbf{O}_{\mathbf{2}} / \mathbf{N}_{\mathbf{2}}$ \\
\hline CZL & 99 & 97 \\
CZT & 97 & 99 \\
CZST & 97 & 97 \\
ZrL & 63 & 80 \\
ZrT & 85 & 97 \\
S & 58 & 58 \\
\hline
\end{tabular}


The specific reaction rate for soot oxidation was also calculated to evaluate in more detail the ability of ceria-based materials to help the transfer of lattice oxygen to carbon in oxygen-poor atmospheres. The values at different temperatures are reported in Figure 7 . While no oxidation is observed in uncatalyzed reaction at $500{ }^{\circ} \mathrm{C}$ (S@500 in Figure 7), for zirconia, both in tight and loose contact, in the $400-500{ }^{\circ} \mathrm{C}$ temperature range, the specific reaction rate is quite low, and does not exceed $300 \mu \mathrm{g}_{\text {soot }} / \mathrm{g}_{\text {soot }}{ }^{*} \mathrm{~s}^{*} \mathrm{~m}^{2}$. For $\mathrm{CZ}$, higher reaction rate values are observed regardless of the contact type, and the rates increase as the contact become more intimate (CZST $>$ CZT $>$ CZL).

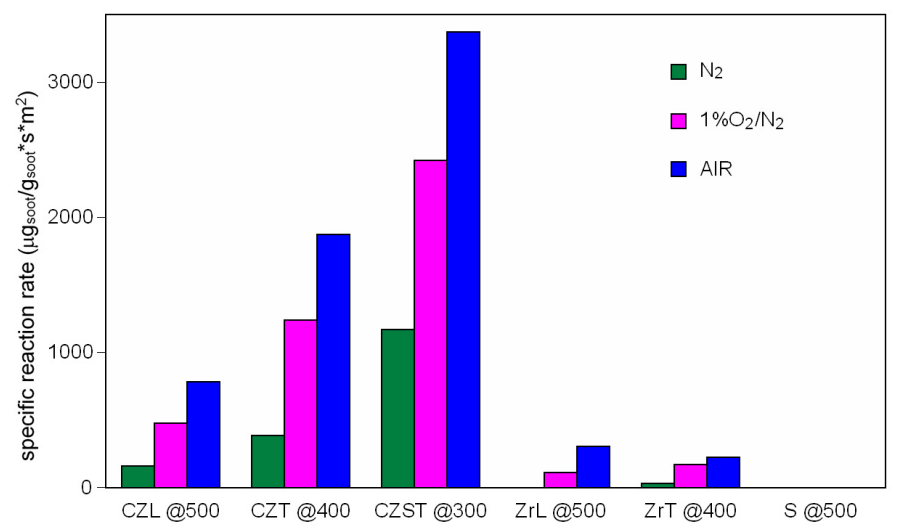

Figure 7. Specific reaction rate for different contact conditions and different reaction atmospheres.

In an oxygen-poor atmosphere, ceria-zirconia has a specific reaction rate from four (CZL) to seven (CZT) times higher than the corresponding zirconia-based systems, confirming the importance of the redox behavior for oxidation under low oxygen pressure.

We have previously reported that soot oxidation over ceria-based catalysts is driven by two different coexisting phenomena, one influenced by the amount of surface active oxygens that predominates in oxygen rich atmosphere, and another related to the OSC (bulk oxygen) of the material that prevails when gas-phase oxygen is absent [47]. In particular, (i) oxygen withdrawn from ceria-zirconia oxidizes carbon at the soot catalyst interface; and (ii) the resulting vacancy or other surface defects can be the center for the activation of gas phase oxygen and the formation of active oxygen species that contributes to oxidize soot on a parallel route. In the absence of gas phase oxygen, route (i) is the only available way to oxidize carbon, while in the presence of oxygen, the two mechanisms may coexist in proportions that depend on oxygen partial pressure and the degree of carbon catalyst contact. The concurrence of the two mechanisms could therefore be important in GPF applications, where the oxygen concentration is lower than in DPF.

Overall, the results obtained in this study highlight the characteristics of materials for use in the catalytic oxidation of particulate matter under oxygen-poor conditions such as those found in GDI engines. It is shown that the activation and transfer of lattice/surface oxygen are fundamental in order to develop catalytic materials suitable for GPF. Ceria-zirconia compositions overtake $\mathrm{ZrO}_{2}$ in both activity and selectivity under these conditions; several known strategies could then be accomplished to increase the transfer of oxygen in these materials, like the engineering of the shape and size of ceria particles (nanocubes, nanorods, etc.) or tailoring the composition of the materials, by lattice/surface doping with rare earth, noble or transition metals elements.

\section{Materials and Methods}

\subsection{Catalyst Preparation}

The ceria-zirconia $\left(\mathrm{Ce}_{0.8} \mathrm{Zr}_{0.2} \mathrm{O}_{2}, \mathrm{CZ} 80\right)$ sample was prepared by the co-precipitation of an acidic solution of cerium and zirconium nitrate (Treibacher Industrie AG, Althofen, Austria) with $\mathrm{NH}_{4} \mathrm{OH}$ in the presence of $\mathrm{H}_{2} \mathrm{O}_{2}$. The precipitate was dried overnight at $100{ }^{\circ} \mathrm{C}$, and calcined in air at $500{ }^{\circ} \mathrm{C}$ for 
$3 \mathrm{~h}$. Zirconia was synthesized by the calcination of zirconium hydroxides (Mel Chemicals, Manchester, UK) at $500{ }^{\circ} \mathrm{C}$ for $3 \mathrm{~h}$. Conventional catalyst/soot mixtures were obtained in loose (L) and tight (T) contact modes by mixing the appropriate amount of catalyst $\left(\mathrm{CZ} 80\right.$ or $\left.\mathrm{ZrO}_{2}\right)$ with soot (Printex $\mathrm{U}$ by Degussa, Esse, Germany, surface area of $100 \mathrm{~m}^{2} / \mathrm{g}$ ), respectively, in a vial for $2 \mathrm{~min}$ or in an agate mortar for $10 \mathrm{~min}$. The catalyst/soot weight ratio of 20:1 was adopted in this study. For CZ80, improved contact (supertight, ST) was achieved in a high-energy Spex mill equipped with a zirconia jar and balls [40]. A reference sample, to obtain the non-catalytic combustion profile, was prepared diluting soot with powder quartz (Carlo Erba Reagents S.r.l., Milan, Italy) in a weight ratio of 1:20.

\subsection{Catalyst Characterization}

Surface area of the materials has been measured by means of a Tristar 3000 gas adsorption analyzer (Micromeritics, Norcross, GA, USA), according to the B.E.T. method by nitrogen adsorption at $77 \mathrm{~K}$. Structural features of the catalysts were investigated by XRD. Diffractograms were recorded on a Philips $X^{\prime}$ Pert diffractometer (Ni-filtered $\mathrm{Cu}-\mathrm{K} \alpha$ radiation) in the range $20^{\circ}-145^{\circ}$ using a step size of $0.02^{\circ}$ and a counting time of $40 \mathrm{~s}$ per angular abscissa (PANalytical B.V., Almelo, the Netherlands). Phase identification has been performed by means of Philips X'Pert HighScore software (Version 1.0b, PANalytical B.V., Almelo, the Netherlands).

In TPR experiments, the catalysts $(50 \mathrm{mg})$ were heated at a constant rate $\left(10{ }^{\circ} \mathrm{C} / \mathrm{min}\right)$ in a U-shaped quartz reactor from room temperature to $900^{\circ} \mathrm{C}$ under a flowing hydrogen/nitrogen mixture ( $35 \mathrm{~mL} / \mathrm{min}, 4.5 \% \mathrm{H}_{2}$ in $\mathrm{N}_{2}$ ). The hydrogen consumption was monitored using a thermal conductivity detector (TCD). For $\mathrm{ZrO}_{2}$ and $\mathrm{Ce}_{0.8} \mathrm{Zr}_{0.2} \mathrm{O}_{2}$, pretreatment under air at $500{ }^{\circ} \mathrm{C}$ for $1 \mathrm{~h}$ was carried out. The outlet gas composition was also followed by an online quadrupole mass-spectrometer (Omnistar, Balzers Instruments, Balzers, Liechtenstein). In addition, $\mathrm{H}_{2}$-TPR experiments under $1.8 \% \mathrm{H}_{2}$ in $\mathrm{N}_{2}$ (total flow $500 \mathrm{~mL} / \mathrm{min}$ ) in a tubular quartz reactor followed by FTIR gas analyzers (MultiGas 2030, MKS Instrumentrs, Inc., Andover, MA, USA) have been performed.

The OSC of samples was investigated by carrying out TGA experiments (Q500, TA Instruments, New Castle, DE) in $4.5 \% \mathrm{H}_{2}$ in $\mathrm{N}_{2}$ mixture flow $(100 \mathrm{~mL} / \mathrm{min})$. Each sample was treated in $\mathrm{N}_{2}$ atmosphere for $1 \mathrm{~h}$ at $150{ }^{\circ} \mathrm{C}$, followed by heating at a constant rate $\left(10{ }^{\circ} \mathrm{C} / \mathrm{min}\right)$ up to a fixed temperature $\left(300,400\right.$ and $\left.500{ }^{\circ} \mathrm{C}\right)$, and finally the $\mathrm{N}_{2} / \mathrm{H}_{2}$ mixture was introduced while keeping that temperature for $60 \mathrm{~min}$. The observed weight loss is due to oxygen removal by $\mathrm{H}_{2}$ to form water, and it can be associated with total oxygen storage capacity at that temperature.

\subsection{Catalytic Activity}

The soot oxidation activity was measured by running thermogravimetric analysis from r.t. to $800{ }^{\circ} \mathrm{C}$ (heating rate $10{ }^{\circ} \mathrm{C} / \mathrm{min}$ ) under a different atmosphere $\left(\mathrm{N}_{2}, 1 \% \mathrm{O}_{2} / \mathrm{N}_{2}\right.$ and air) [48,49]. Before the catalytic tests, the samples (soot + catalyst, ca. $20 \mathrm{mg}$ ) were subjected to a $1 \mathrm{~h}$ pre-treatment at $150{ }^{\circ} \mathrm{C}$ under inert atmosphere $(60 \mathrm{~mL} / \mathrm{min})$, in order to eliminate the adsorbed water. The activity was measured by means of T50, the temperature at which $50 \%$ of the weight loss is observed. Catalytic activity measurements have also been carried out by TPO experiments heating at a constant rate $\left(10^{\circ} \mathrm{C} / \mathrm{min}\right) 20 \mathrm{mg}$ of sample under $\mathrm{O}_{2}$ gas flow $\left(1 \%\right.$ or $10 \% \mathrm{O}_{2}(v / v)$ balance $\mathrm{N}_{2}$; total flow $\left.0.5 \mathrm{~L} / \mathrm{min}\right)$. The catalyst temperature was measured by a chromel-alumel thermocouple, located on the catalyst bed. The outlet gas composition (i.e., $\mathrm{CO}$, and $\mathrm{CO}_{2}$ ) was measured by FTIR gas analyzers (MultiGas 2030, MKS Instrumentrs, Inc., Andover, MA, USA). As a matter of fact, reproducibility of results was verified by running several TGA/TPO experiments on similar samples, and the results, in terms of $\mathrm{T} 50 / \mathrm{Tp}$, were always within $\pm 3^{\circ} \mathrm{C}$.

Reaction rate measurements were performed by TGA isothermal experiments after pretreatment of ca. $20 \mathrm{mg}$ of a catalyst-soot mixture under nitrogen atmosphere for $1 \mathrm{~h}$ at $150{ }^{\circ} \mathrm{C}$. Then the temperature has been increased at a constant rate $\left(10^{\circ} \mathrm{C} / \mathrm{min}\right)$ up to the reaction temperature $\left(300,400\right.$ or $\left.500{ }^{\circ} \mathrm{C}\right)$, followed by switching to air. The reaction was followed for $1 \mathrm{~h}$. A specific reaction rate has been determined, according to Van Setten et al. [50], and normalized to the soot initially present in the 
reactor and to the catalyst surface area $\left(\mu \mathrm{g}_{\text {soot }} /\left(\mathrm{g}_{\text {sootinitial }} \cdot \mathrm{s} \cdot \mathrm{m}^{2}\right)\right.$ [51]. The reaction rate was calculated at $3 \%$ of conversion. A reaction rate in an inert atmosphere has also been performed.

\section{Conclusions}

Ceria-based materials has been widely studied as a catalyst in diesel particulate filters, but their role and applicability in gasoline particulate filters, under oxygen-poor conditions, is still at the initial stage, and this preliminary work investigates their potential in soot oxidation at low oxygen partial pressure. The comparison of the behavior of ceria-zirconia and zirconia in soot oxidation shows that the former is less influenced by the variation of the oxygen atmosphere, and is capable of carbon oxidation at a lower temperature with almost full selectivity to $\mathrm{CO}_{2}$; in contrast, activity in $\mathrm{ZrO}_{2}$ is highly influenced by the oxygen atmosphere, and lower $\mathrm{CO}_{2}$ selectivities are obtained. Lattice and surface oxygen in ceria-zirconia can help with oxidation at low oxygen partial pressure. The mechanism works through the interface between carbon and catalysts, and is therefore highly dependent on the way carbon and catalysts are put into contact. The presence of soot over ceria-zirconia particles acts as a driving force for the reduction of the material enhancing the oxygen removal rate, and its use in oxidation reaction in the substitution of gas phase oxygen.

Author Contributions: E.A.: conceptualization, data curation, investigation, methodology, writing-original draft, writing-review \& editing; A.T.: supervision, writing-review \& editing. All authors have read and agreed to the published version of the manuscript.

Funding: This research was funded in part by Interreg V Italy-Austria project COAT4CATA project number ITAT1019.

Conflicts of Interest: The authors declare no conflict of interest.

\section{References}

1. Spiess, S.; Wong, K.-F.; Richter, J.-M.; Klingmann, R. Investigations of Emission Control Systems for Gasoline Direct Injection Engines with a Focus on Removal of Particulate Emissions. Top Catal. 2013, 56, 434-439. [CrossRef]

2. Union, E. Regulation (EU) No 333/2014 of the European Parliament and of the Council of 11 March 2014 amending Regulation (EC) $\mathrm{N}^{\circ} 443 / 2009$ to define the modalities for reaching the 2020 target to reduce $\mathrm{CO}_{2}$ emissions from new passenger cars. Off. J. Eur. Union 2014, 103, 15-21.

3. Guan, B.; Zhan, R.; Lin, H.; Huang, Z. Review of the state-of-the-art of exhaust particulate filter technology in internal combustion engines. J. Environ. Manag. 2015, 154, 225-258. [CrossRef]

4. Nicolin, P.; Rose, D.; Kunath, F.; Boger, T. Modeling of the Soot Oxidation in Gasoline Particulate Filters. SAE Int. J. Engines 2015, 8, 1253-1260. [CrossRef]

5. Lambert, C.; Chanko, T.; Dobson, D.; Liu, X.; Pakko, J. Gasoline Particle Filter Development. Emiss. Control Sci. Technol. 2017, 3, 105-111. [CrossRef]

6. Johnson, T.; Joshi, A. Review of Vehicle Engine Efficiency and Emissions. SAE Int. J. Engines 2018, 11, 1307-1330. [CrossRef]

7. Bogarra, M.; Herreros, J.M.; Tsolakis, A.; Rodriguez-Fernandez, J.; York, A.P.E.; Millington, P.J. Gasoline direct injection engine soot oxidation: Fundamentals and determination of kinetic parameters. Combust. Flame 2018, 190, 177-187. [CrossRef]

8. Lopez-Gonzalez, D.; Tsampas, M.N.; Boreave, A.; Retailleau-Mevel, L.; Klotz, M.; Tardivat, C.; Cartoixa, B.; Pajot, K.; Vernoux, P. Mixed Ionic-Electronic Conducting Catalysts for Catalysed Gasoline Particulate Filters. Top Catal. 2015, 58, 1242-1255. [CrossRef]

9. Liu, S.; Wu, X.D.; Liu, W.; Chen, W.M.; Ran, R.; Li, M.; Weng, D. Soot oxidation over $\mathrm{CeO}_{2}$ and $\mathrm{Ag} / \mathrm{CeO}_{2}$ : Factors determining the catalyst activity and stability during reaction. J. Catal. 2016, 337, 188-198. [CrossRef]

10. Hernandez, W.Y.; Tsampas, M.N.; Zhao, C.; Boreave, A.; Bosselet, F.; Vernoux, P. La/Sr-based perovskites as soot oxidation catalysts for Gasoline Particulate Filters. Catal. Today 2015, 258, 525-534. [CrossRef]

11. Hernandez, W.Y.; Lopez-Gonzalez, D.; Ntais, S.; Zhao, C.; Boreave, A.; Vernoux, P. Silver-modified manganite and ferrite perovskites for catalyzed gasoline particulate filters. Appl. Catal. B Environ. 2018, 226, 202-212. [CrossRef] 
12. Moreno-Marcos, C.; Torregrosa-Rivero, V.; Albaladejo-Fuentes, V.; Sanchez-Adsuar, M.S.; Illan-Gomez, M.J. $\mathrm{BaFe}_{1-\mathrm{x}} \mathrm{Cu}_{\mathrm{x}} \mathrm{O}_{3}$ Perovskites as Soot Oxidation Catalysts for Gasoline Particulate Filters (GPF): A Preliminary Study. Top Catal. 2019, 62, 413-418. [CrossRef]

13. Yang, W.N.; Wang, S.M.; Li, K.Z.; Liu, S.; Gan, L.N.; Peng, Y.; Li, J.H. Highly selective $\alpha-\mathrm{Mn}_{2} \mathrm{O}_{3}$ catalyst for cGPF soot oxidation: Surface activated oxygen enhancement via selective dissolution. Chem. Eng. J. 2019, 364, 448-451. [CrossRef]

14. Fino, D.; Bensaid, S.; Piumetti, M.; Russo, N. A review on the catalytic combustion of soot in Diesel particulate filters for automotive applications: From powder catalysts to structured reactors. Appl. Catal. A Gen. 2016, 509, 75-96. [CrossRef]

15. Liu, S.; Wu, X.D.; Weng, D.; Ran, R. Ceria-based catalysts for soot oxidation: A review. J. Rare Earth 2015, 33, 567-590. [CrossRef]

16. Hernandez-Gimenez, A.M.; Castello, D.L.; Bueno-Lopez, A. Diesel soot combustion catalysts: Review of active phases. Chem. Pap. 2014, 68, 1154-1168. [CrossRef]

17. Aneggi, E.; de Leitenburg, C.; Trovarelli, A. Ceria-based formulations for catalysts for diesel soot combustion. In Catalysis by Ceria and Related Materials, 2nd ed.; Alessandro, T., Paolo, F., Eds.; Imperial College Press: London, UK, 2013; pp. 565-621.

18. di Sarli, V.; Landi, G.; Lisi, L.; di Benedetto, A. Ceria-Coated Diesel Particulate Filters for Continuous Regeneration. Aiche J. 2017, 63, 3442-3449. [CrossRef]

19. di Sarli, V.; Landi, G.; Lisi, L.; Saliva, A.; di Benedetto, A. Catalytic diesel particulate filters with highly dispersed ceria: Effect of the soot-catalyst contact on the regeneration performance. Appl. Catal. B Environ. 2016, 197, 116-124. [CrossRef]

20. Bueno-Lopez, A. Diesel soot combustion ceria catalysts. Appl. Catal. B Environ. 2014, 146, 1-11. [CrossRef]

21. Montini, T.; Melchionna, M.; Monai, M.; Fornasiero, P. Fundamentals and Catalytic Applications of CeO2-Based Materials. Chem. Rev. 2016, 116, 5987-6041. [CrossRef]

22. Devaiah, D.; Reddy, L.H.; Park, S.E.; Reddy, B.M. Ceria-zirconia mixed oxides: Synthetic methods and applications. Catal. Rev. 2018, 60, 177-277. [CrossRef]

23. Trovarelli, A. Catalytic properties of ceria and $\mathrm{CeO}_{2}$-containing materials. Catal. Rev. 1996, 38, 439-520. [CrossRef]

24. Soler, L.; Casanovas, A.; Escudero, C.; Perez-Dieste, V.; Aneggi, E.; Trovarelli, A.; Llorca, J. Ambient Pressure Photoemission Spectroscopy Reveals the Mechanism of Carbon Soot Oxidation in Ceria-Based Catalysts. Chemcatchem 2016, 8, 2748-2751. [CrossRef]

25. Bueno-Lopez, A.; Krishna, K.; Makkee, M.; Moulijn, J. Active oxygen from $\mathrm{CeO}_{2}$ and its role in catalysed soot oxidation. Catal. Lett. 2005, 99, 203-205. [CrossRef]

26. Machida, M.; Murata, Y.; Kishikawa, K.; Zhang, D.J.; Ikeue, K. On the reasons for high activity of $\mathrm{CeO}_{2}$ catalyst for soot oxidation. Chem. Mater. 2008, 20,4489-4494. [CrossRef]

27. Aneggi, E.; Llorca, J.; de Leitenburg, C.; Dolcetti, G.; Trovarelli, A. Soot combustion over silver-supported catalysts. Appl. Catal. B Environ. 2009, 91, 489-498. [CrossRef]

28. Shimizu, K.; Kawachi, H.; Satsuma, A. Study of active sites and mechanism for soot oxidation by silver-loaded ceria catalyst. Appl. Catal. B Environ. 2010, 96, 169-175. [CrossRef]

29. Yamazaki, K.; Kayama, T.; Dong, F.; Shinjoh, H. A mechanistic study on soot oxidation over $\mathrm{CeO}_{2}-\mathrm{Ag}$ catalyst with 'rice-ball' morphology. J. Catal. 2011, 282, 289-298. [CrossRef]

30. Castoldi, L.; Aneggi, E.; Matarrese, R.; Bonzi, R.; Llorca, J.; Trovarelli, A.; Lietti, L. Silver-based catalytic materials for the simultaneous removal of soot and NOx. Catal. Today 2015, 258, 405-415. [CrossRef]

31. Gao, Y.X.; Duan, A.Q.; Liu, S.; Wu, X.D.; Liu, W.; Li, M.; Chen, S.G.; Wang, X.; Weng, D. Study of $\mathrm{Ag} / \mathrm{Ce}_{\mathrm{x}} \mathrm{Nd}_{1-\mathrm{x}} \mathrm{O}_{2}$ nanocubes as soot oxidation catalysts for gasoline particulate filters: Balancing catalyst activity and stability by Nd doping. Appl. Catal. B Environ. 2017, 203, 116-126. [CrossRef]

32. Wang, H.L.; Liu, S.; Zhao, Z.; Zou, X.; Liu, M.H.; Liu, W.; Wu, X.D.; Weng, D. Activation and deactivation of $\mathrm{Ag} / \mathrm{CeO}_{2}$ during soot oxidation: Influences of interfacial ceria reduction. Catal. Sci. Technol. 2017, 7, 2129-2139. [CrossRef]

33. Wang, H.L.; Luo, S.T.; Li, X.H.; Liu, W.; Wu, X.D.; Weng, D.; Liu, S. Thermally stable $\mathrm{Ag} / \mathrm{Al}_{2} \mathrm{O}_{3}$ confined catalysts with high diffusion-induced oxidation activity. Catal. Today 2019, 332, 189-194. [CrossRef] 
34. Wang, H.; Jin, B.; Wang, H.; Ma, N.; Liu, W.; Weng, D.; Wu, X.; Liu, S. Study of Ag promoted $\mathrm{Fe}_{2} \mathrm{O}_{3} @ \mathrm{CeO}_{2}$ as superior soot oxidation catalysts: The role of $\mathrm{Fe}_{2} \mathrm{O}_{3}$ crystal plane and tandem oxygen delivery. Appl. Catal. B Environ. 2018, 237, 251-262. [CrossRef]

35. Wu, S.J.; Yang, Y.; Lu, C.X.; Ma, Y.Y.; Yuan, S.X.; Qian, G.R. Soot Oxidation over $\mathrm{CeO}_{2}$ or Ag/CeO 2 : Influences of Bulk Oxygen Vacancies and Surface Oxygen Vacancies on Activity and Stability of the Catalyst. Eur. J. Inorg. Chem. 2018, 25, 2944-2951. [CrossRef]

36. Wang, R.; Lan, L.; Gong, M.C.; Chen, Y.Q. Catalytic Combustion of Gasoline Particulate Soot over $\mathrm{CeO}_{2}-\mathrm{ZrO}_{2}$ Catalysts. Acta Phys.Chim. Sin. 2016, 32, 1747-1757. [CrossRef]

37. Liu, S.; Wu, X.D.; Tang, J.; Cui, P.Y.; Jiang, X.Q.; Chang, C.G.; Liu, W.; Gao, Y.X.; Li, M.; Weng, D. An exploration of soot oxidation over $\mathrm{CeO}_{2}-\mathrm{ZrO}_{2}$ nanocubes: Do more surface oxygen vacancies benefit the reaction? Catal. Today 2017, 281, 454-459. [CrossRef]

38. Martinez-Munuera, J.C.; Zoccoli, M.; Gimenez-Manogil, J.; Garcia-Garcia, A. Lattice oxygen activity in ceria-praseodymia mixed oxides for soot oxidation in catalysed Gasoline Particle Filters. Appl. Catal. B Environ. 2019, 245, 706-720. [CrossRef]

39. Park, C.S.; Lee, M.W.; Lee, J.H.; Jeong, E.J.; Lee, S.H.; Choung, J.W.; Kim, C.H.; Ham, H.C.; Lee, K.Y. Promoting effect of $\mathrm{H}_{2} \mathrm{O}$ over macroporous Ce-Zr catalysts in soot oxidation. Mol. Catal. 2019, 474, 110416. [CrossRef]

40. Aneggi, E.; Rico-Perez, V.; de Leitenburg, C.; Maschio, S.; Soler, L.; Llorca, J.; Trovarelli, A. Ceria-Zirconia Particles Wrapped in a 2D Carbon Envelope: Improved Low-Temperature Oxygen Transfer and Oxidation Activity. Angew Chem. Int. Edit. 2015, 54, 14040-14043. [CrossRef]

41. Aneggi, E.; Llorca, J.; Trovarelli, A.; Aouine, M.; Vernoux, P. In situ environmental HRTEM discloses low temperature carbon soot oxidation by ceria-zirconia at the nanoscale. Chem. Commun. 2019, 55, 3876-3878. [CrossRef]

42. Neeft, J.P.A.; Makkee, M.; Moulijn, J.A. Metal oxides as catalysts for the oxidation of soot. Chemical. Eng. J. 1996, 64, 295-302. [CrossRef]

43. Balaz, P.; Achimovicova, M.; Balaz, M.; Billik, P.; Cherkezova-Zheleva, Z.; Criado, J.M.; Delogu, F.; Dutkova, E.; Gaffet, E.; Gotor, F.J.; et al. Hallmarks of mechanochemistry: From nanoparticles to technology. Chem. Soc. Rev. 2013, 42, 7571-7637. [CrossRef] [PubMed]

44. Fally, F.; Perrichon, V.; Vidal, H.; Kaspar, J.; Blanco, G.; Pintado, J.M.; Bernal, S.; Colon, G.; Daturi, M.; Lavalley, J.C. Modification of the oxygen storage capacity of $\mathrm{CeO}_{2}-\mathrm{ZrO}_{2}$ mixed oxides after redox cycling aging. Catal. Today 2000, 59, 373-386. [CrossRef]

45. Aneggi, E.; Leitenburg, C.D.; Trovarelli, A. Influence of Nanoscale Surface Arrangements on the Oxygen Transfer Ability of Ceria-Zirconia Mixed Oxide. Inorganics 2020, 8, 34. [CrossRef]

46. Aneggi, E.; Divins, N.J.; de Leitenburg, C.; Llorca, J.; Trovarelli, A. The formation of nanodomains of $\mathrm{Ce}_{6} \mathrm{O}_{11}$ in ceria catalyzed soot combustion. J. Catal. 2014, 312, 191-194. [CrossRef]

47. Aneggi, E.; de Leitenburg, C.; Trovarelli, A. On the role of lattice/surface oxygen in ceria-zirconia catalysts for diesel soot combustion. Catal. Today 2012, 181, 108-115. [CrossRef]

48. Carrascull, A.; Grzona, C.; Lick, D.; Ponzi, M.; Ponzi, E. Soot combustion. CO and K catalysts supported on different supports. React. Kinet. Catal. L 2002, 75, 63-68. [CrossRef]

49. Lamonier, J.F.; Sergent, N.; Matta, J.; Aboukais, A. Caracterization of $\mathrm{Zr}_{\mathrm{x}} \mathrm{Ce}_{1-\mathrm{x}} \mathrm{O}_{2}$ catalysts and analysis of their reactivity in carbon soot oxidation by TGA/DTA. J. Therm. Anal. Calorim. 2001, 66, 645-658. [CrossRef]

50. van Setten, B.A.A.L.; van Dijk, R.; Jelles, S.J.; Makkee, M.; Moulijn, J.A. The potential of supported molten salts in the removal of soot from diesel exhaust gas. Appl. Catal. B Environ. 1999, 21, 51-61. [CrossRef]

51. Aneggi, E.; de Leitenburg, C.; Llorca, J.; Trovarelli, A. Higher activity of Diesel soot oxidation over polycrystalline ceria and ceria-zirconia solid solutions from more reactive surface planes. Catal. Today 2012, 197, 119-126. [CrossRef]

(C) 2020 by the authors. Licensee MDPI, Basel, Switzerland. This article is an open access article distributed under the terms and conditions of the Creative Commons Attribution (CC BY) license (http://creativecommons.org/licenses/by/4.0/). 